\title{
Pengaruh Pembelajaran Savi (Somatic, Auditory, Visual, Intellectual) terhadap Kemampuan Pemecahan Masalah Ditinjau dari Tingkat Kemampuan Awal Matematika Siswa SMK
}

\author{
Riam Nurussilmah $^{1, a)}$, Vera Maya Santi ${ }^{2, \text { b) }}$, Tian Abdul Aziz ${ }^{3, c)}$ \\ 1,2,3 Universitas Negeri Jakarta \\ Email:a) riamnrsslmh@gmail.com, ${ }^{\text {b) }}$ vmsanti@unj.ac.id, ${ }^{\text {c) }}$ tian_aziz@unj.ac.id
}

\begin{abstract}
Abstrak
Penelitian ini bertujuan untuk menguji apakah penerapan model pembelajaran SAVI (Somatic, Auditory, Visual, Intellectual) terhadap kemampuan pemecahan masalah matematika ditinjau dari tingkat kemampuan awal matematika siswa kelas X SMK. Penelitian ini menggunakan metode quasi experiment dengan Post- Test Only Non-equivalent Control Group Design. Pengambilan sampel dengan teknik cluster random sampling. Kelas eksperimen terdiri atas 36 siswa, yang mendapat perlakuan berupa model pembelajaran SAVI dan kelas kontrol terdiri dari 32 siswa yang diajarkan dengan model pembelajaran konvensional. Instrumen yang digunakan adalah tes kemampuan awal matematika dan tes kemampuan pemecahan masalah yang dikembangkan oleh peneliti dan memiliki tingkat validitas dan reliabilitas sangat tinggi. Berdasarkan hasil pengujian hipotesis statistik menggunakan uji ANAVA RAK diperoleh bahwa model pembelajaran SAVI dan konvensional yang dilakukan tidak memberi pengaruh dalam mengendalikan kemampuan pemecahan masalah matematika siswa. Selain itu, berdasarkan tingkat kemampuan awal matematika terdapat perbedaan terhadap kemampuan pemecahan masalah matematika siswa. Kemudian, dengan Uji Duncan (DMRT) diperoleh hasil bahwa model SAVI dengan tingkat kemampuan awal matematika rendah lebih baik dari model konvensional dalam kemampuan pemecahan masalah matematika siswa.
\end{abstract}

Kata Kunci: Model Pembelajaran SAVI, Kemampuan Pemecahan Masalah Matematis, Tingkat Kemampuan Awal Matematika

\section{PENDAHULUAN}

Matematika merupakan ilmu yang mendasari perkembangan teknologi, karena mempunyai peran penting dalam berbagai disiplin ilmu dan memajukan daya pikir manusia (Ulfa, Buchori, \& Murtianto, 2017). Matematika sebagai aktivitas manusia yang berarti manusia diberi kesempatan untuk menemukan kembali ide dan konsep matematika dengan bimbingan yang lebih dewasa (Lutfianto, Zulkardi, \& Hartono, 2013).

NCTM (2000) menyatakan terdapat lima kemampuan yang dipelajari siswa saat mereka belajar matematika, salah satu kemampuan tersebut adalah kemampuan pemecahan masalah. Kecakapan menerapkan pengetahuan yang diperoleh sebelumnya ke dalam situasi yang belum dikenal (Ulfa dkk., 2017). Pemecahan masalah menurut pendapat Anderson (Ulfa dkk., 2017) merupakan keterampilan hidup yang melibatkan proses menganalisis, menafsirkan, menalar, memprediksi, mengevaluasi dan merefleksikan. Jadi, kemampuan pemecahan masalah adalah kemampuan untuk menerapkan pengetahuan yang telah dimiliki sebelumnya ke dalam situasi baru yang melibatkan proses berpikir tingkat tinggi.

Kemampuan pemecahan masalah matematika siswa di Indonesia tergolong rendah (Ulfa dkk., 2017). Hal ini dapat dilihat dari rata-rata nilai Ujian Nasional (UN) matematika mulai dari jenjang pendidikan dasar sampai menengah atas yang relatif rendah. Berdasarkan hasil Ujian Nasional (UN) dari data Puspendik rata-rata nilai Ujian Nasional (UN) matematika siswa SMK tahun 2019 adalah 
35,25\% hasil ini relatif rendah di bandingkan dengan mata pelajaran lainnya seperti Bahasa Indonesia, Bahasa Inggris serta kompetensi. PISA (Programme for International Student Assessment) juga mencerminkan rendahnya kemampuan pemecahan masalah matematika siswa. Berdasarkan hasil PISA 2018 untuk matematika dan sains yang juga menjadi pekerjaan rumah besar bagi Indonesia (Harususilo, 2019). Rerata skor PISA negara anggota OECD untuk matematika 489 Indonesia. Mengikuti tes PISA sejak tahun 2000, pada tahun 2018 skor PISA Indonesia untuk matematika berkisar di angka 379 di skor 396. Sebagai pembanding, China dan Singapura menempati peringkat tinggi untuk skor matematika dengan skor 591 dan 569 (Harususilo, 2019).

Pembelajaran konvensional yang masih diterapkan di sekolah merupakan salah satu faktor penyebab rendahnya kemampuan pemecahan masalah matematika. Suatu proses pembelajaran dikatakan baik jika proses tersebut dapat membangkitkan kegiatan belajar siswa, siswa yang melakukan kegiatan untuk mencari, menemukan, memecahkan masalah, menyimpulkan dan memahami ilmu pengetahuan. pembelajaran SAVI adalah pembelajaran yang menekankan bahwa belajar haruslah memanfaatkan semua alat indera yang dimiliki siswa, mencakup: Somatic yang bermakna gerakan tubuh (hands-on, aktivitas fisik) di mana belajar dengan mengalami dan melakukan; Auditory yang bermakna bahwa belajar haruslah dengan melalui mendengarkan, menyimak, berbicara, presentasi, argumentasi, mengemukakan pendapat, dan menanggapi; Visual yang bermakna belajar haruslah menggunakan indera mata melalui mengamati, menggambar, mendemonstrasikan, membaca, menggunakan media dan alat peraga; dan Intellectual yang bermakna bahwa belajar haruslah menggunakan kemampuan berpikir (minds-on). Belajar haruslah dengan konsentrasi pikiran dan berlatih menggunakannya melalui bernalar, menyelidiki, mengidentifikasi, menemukan, mencipta, mengkonstruksi, memecahkan masalah, dan menerapkan.

Model pembelajaran SAVI dari kata Somatic, Auditory, Visual, dan Intelectuall adalah model pembelajaran yang diharapkan siswa untuk melibatkan aktivitas fisik. Model pembelajaran ini akan mengajak siswa belajar dengan berbuat dan bergerak, berbicara dan mendengar, mengamati dan menggambarkan serta memecahkan masalah, sehingga siswa akan menggunakan semua inderanya untuk belajar (Meier, 2002). Belajar bisa optimal jika keempat unsur SAVI ada dalam suatu peristiwa pembelajaran. Siswa dapat meningkatkan kemampuan mereka memecahkan masalah (Intellectual) jika mereka secara simultan menggerakkan sesuatu (Somatic) untuk menghasilkan piktogram atau pajangan tiga dimensi (Visual) sambil membicarakan apa yang sedang mereka kerjakan (Auditory). Menggabungkan keempat modalitas belajar dalam satu peristiwa pembelajaran adalah inti dari pembelajaran multi indriawi seperti pembelajaran SAVI. Penelitian terdahulu yang relevan dengan penelitian ini disajikan singkat dalam uraian berikut:

1. Penelitian yang berjudul "Kemampuan Pemecahan Masalah Matematis Siswa ditinjau melalui Model Pembelajaran SAVI dan Konvensional" oleh Ulvah dan Afriansyah (2016) pada siswa kelas VIII MTs Muhammadiyah Bayubud, diperoleh kemampuan pemecahan masalah matematika pada materi pokok bahasan kubus dan balok kelas VIII dengan menggunakan Uji Mann Whitney. Peningkatan kemampuan pemecahan masalah matematis siswa pada kelas eksperimen dan kelas kontrol adalah sedang. Hal ini berdasarkan hasil analisis data gain ternormalisasi untuk kelas keduanya berada pada interval yang berinterpretasi sedang.

2. Penelitian yang berjudul "Pembelajaran Model SAVI Berpendekatan Kontekstual Terhadap Kemampuan Pemecahan Masalah Matematika Siswa" oleh Taneo (2017) pada siswa kelas VII SMP Negeri 1 Soe, Kabupaten Timor Tengah Selatan pemecahan masalah siswa kelas VII SMP Negeri 1 Soe mencapai ketuntasan yang baik secara individual maupun klasikal. Hal ini menunjukan bahwa rata- rata kemampuan pemecahan masalah siswa melampaui rata-rata asumsi populasi. Sedangkan ketuntasan klasikal dari perhitungan diperoleh bahwa siswa yang diajarkan dengan model SAVI berpendekatan kontekstual tuntas secara klasikal. Dengan demikian, dapat disimpulkan bahwa kemampuan pemecahan masalah siswa pada kelas yang mendapat pembelajaran model SAVI berpendekatan kontekstual mencapai ketuntasan minimal.

3. Penelitian yang berjudul "Hasil Eksperimen Model Pembelajaran SAVI dan PBL Materi Gerak Lurus Kelas X MIA SMA N 4 Surakarta Ditinjau dari Kemampuan Berpikir Kritis Siswa” oleh Sumarni dkk., (2017) pada kelas X MIA di SMA Negeri 4 Surakarta. Hasil uji ANAVA dua jalan dengan isi sel tak sama diperoleh ada perbedaan pengaruh kemampuan kognitif siswa yang diberi 
pembelajaran SAVI (kelas eksperimen I) dan PBL (kelas eksperimen II) Berdasarkan uji analisis variansi dua jalan dengan frekuensi sel tak sama diperoleh tidak ada interaksi pengaruh antara penerapan model pembelajaran dengan kemampuan berpikir kritis siswa terhadap kemampuan kognitif siswa. Penerapan hal ini berarti ada perbedaan pengaruh kemampuan berpikir kritis siswa kategori tinggi dan rendah terhadap kemampuan kognitif siswa.

Indikator yang digunakan untuk mengukur kemampuan pemecahan masalah matematis siswa pada penelitian ini menggunakan indikator Eka Lestari (2015) adalah sebagai berikut: (1) Mengidentifikasikan unsur-unsur yang diketahui, ditanyakan, dan kecukupan unsur yang diperlukan, (2) Merumuskan masalah matematis atau menyusun model matematis, (3) Menetapkan strategi untuk menyelesaikan masalah, dan (4) Menjelaskan atau meninterpretasikan hasil penyelesaian masalah. Penerapan model pembelajaran kooperatif tipe SAVI (Somatic, Auditory, Visual, dan Intelectuall) ditinjau dari tingkat kemampuan awal matematika siswa diharapkan dapat memberikan pengaruh yang positif terhadap kemampuan pemecahan masalah matematika siswa. Berdasarkan uraian tersebut, penelitian ini bertujuan untuk mengetahui apakah penerapan model pembelajaran kooperatif tipe SAVI (Somatic, Auditory, Visual, dan Intelectuall) ditinjau dari tingkat kemampuan awal matematika siswa berpengaruh terhadap kemampuan pemecahan masalah matematika siswa. Penelitian ini melanjutkan penelitian sebelumnya oleh Taneo (2017) yang memberikan saran penelitian model pembelajaran yang sama dengan pengkategorian berdasarkan tingkat kemampuan awal matematika siswa. Manfaat penelitian secara teoritis hasil ini diharapkan dapat menambah wawasan ilmu pendidikan bagi guru dalam mengoptimalkan proses pembelajaran dan media pembelajaran yang tepat. Secara praktis bagi penulis, hasil penelitian ini dapat digunakan sebagai sarana untuk mengembangkan dan menambah wawasan tentang model serta teori-teori yang diperoleh dalam bangku kuliah, khususnya dalam bidang pendidikan matematika. Bagi peserta didik, penerapan model pembelajaran kooperatif tipe SAVI (Somatic, Auditory, Visual, Intellectual) diharapkan dapat meningkatkan kepercayaan diri peserta didik sehingga dapat menumbuhkan kemampuan pemecahan masalah matematika siswa dan melatih siswa untuk berpikir cepat dan tersusun secara logis serta dapat berpartisipasi aktif dalam kegiatan pembelajaran matematika dan lebih memaksimalkan kemampuan pemecahan masalah matematikanya. Bagi guru dan sekolah, sebagai sumbangan ide dalam menentukan model dan media pembelajaran yang sesuai dengan materi yang bersangkutan serta cara untuk mengetahui kemampuan pemecahan masalah matematika ditinjau dari tingkat kemampuan awal matematika siswa.

Proses pembelajaran yang tidak beruntun atau tidak terurut dari hal yang dasar menuju hal yang kompleks membuat peserta didik merasa kebingungan dan sukar untuk menerima materi yang lebih kompleks. Dari hal tersebut sebagai pendidik seharusnya mengetahui sejauh mana tingkat kemampuan awal siswa, sebab dalam pelaksanaanya kemampuan awal menjadi landasan pola pikir awal dalam pembelajaran. Perihal tersebut memberi gambaran bahwa kemampuan awal menjadi kemampuan dasar yang perlu diperhatikan dalam suatu pembelajaran khususnya matematika. Kemampuan awal siswa tidak lain adalah kemampuan yang sudah dipunyai oleh siswa sebelum mengikuti pembelajaran yang akan diberikan oleh guru. Kemampuan awal ini 35 dapat diketahui melalui tindakan tes awal sebelum pembelajaran berlangsung. Dengan begitu bobot materi yang disiapkan guru sesuai dengan kemampuan awal yang dimiliki siswa sehingga proses pembelajaran lebih terkonsep dan menarik bagi siswa yang pada giliranya dapat meningkatkan kemampuan matematika siswa.

\section{METODE}

Penelitian ini merupakan penelitian kuantitatif dengan menggunakan quasi eksperimen dan PostTest Only Non-equivalent Control Group Design. Prosedur dalam penelitian ini terdiri atas empat tahap, yaitu tahap persiapan, tahap pelaksanaan, tahap analisis data dan tahap penarikan kesimpulan.

Populasi terjangkau pada penelitian ini adalah seluruh siswa kelas X CP 1, X CP 2 dan X CP 3 SMK Negeri 7 Jakarta. Teknik pengambilan sampel yang digunakan adalah memilih kelas-kelas dengan jurusan yang sama dan teknik cluster random sampling, yaitu untuk menentukan kelas eksperimen dan kelas kontrol. Data yang diambil untuk penelitian ini adalah hasil Penilaian Tengah Semester (PTS) kelas X semester ganjil tahun ajaran 2019/2020 dan hasil post test dengan jumlah siswa kelas eksperimen 36 siswa dan jumlah siswa kelas kontrol 32 siswa. Hasil PTS digunakan untuk uji prasyarat 
analisis data sebelum perlakuan untuk menentukan kelas eksperimen dan kelas kontrol. Instrumen posttest terdiri dari 4 soal dengan validitas dan reliabilitas yang sangat tinggi. Berikut salah satu soal posttest kemampuan pemecahan masalah matematika "Pesawat A dan B berjarak $50 \mathrm{~km}$. Pesawat B letaknya pada arah $100^{\circ}$ dari $A$ dan pesawat $C$ terletak pada $145^{\circ}$ dari A. Pesawat $C$ letaknya pada arah $220^{\circ}$ dari $\mathrm{B}, \sin 75^{\circ}=0,96$. Tentukan jarak pesawat C dari pesawat A dan pesawat B".

Adapan hasil post test digunakan untuk uji prasyarat analisis data setelah perlakuan, uji analisis data dan uji besar pengaruh. Teknik pengumpulan data dilakukan dengan memberikan post test kemampuan pemecahan masalah matematis kepada siswa kelas eksperimen dan kelas kontrol pada bahasan aturan sinus dan cosinus. Instrument post test di validasi oleh dua validator ahli dari dosen pendidikan matematika universitas negeri jakarta dan satu guru matematika di SMK Negeri 7 Jakarta. Kegiatan pembelajaran dikelas kontrol dengan model pembelajaran konvensional siswa diberikan materi secara keseluruhan kemudian memberikan contoh soal per materi dan siswa disuruh maju ke depan untuk menyelesaikan soal-soal tersebut, jika ada kekeliruan dalam penyelesaian siswa yang lain diperbolehkan untuk membenarkan jawabannya, siswa yang lain mencatat contoh soal tersebut di buku. Kegiatan pembelajaran di kelas penelitian yang menerapkan model pembelajaran SAVI dengan pengelompokkan siswa berdasarkan tingkat kemampuan awal matematika siswa terdiri dari kegiatan pendahuluan, kegiatan inti dan kegiatan penutup. Pada kegiatan inti, siswa mengikuti empat tahapan model pemebelajaran SAVI. Tahapan pertama auditory yaitu mengucapkan secara singkat terperinci apa yang sedang mereka baca. Kedua somatic seperti kegiatan simulasi, permainan belajar, menuliskan dan mengerjakan dipapan tulis. Ketiga visual pada tahap ini guru memberikan gambaran yang tepat sesuai dengan materi aturan sinus dan cosinus. Keempat intellectual pada tahap ini siswa diharapkan dapat merumuskan pertanyaan, mencari dan menyaring informasi, menganalisis pengamatan, mengerjakan perencanaan strategis, melahirkan gagasan kreatif, memecahkan masalah.

Teknik analisis data yang digunakan pada penelitian ini adalah uji prasyarat analisis data sebelum perlakuan, uji analisis data dan uji besar pengaruh. Uji prasyarat analisis data sebelum perlakuan terdiri dari uji normalitas menggunakan Uji Liliefors, uji homogenitas menggunakan Uji Bartlett, dan uji kesamaan rata-rata menggunakan Uji ANAVA satu arah, dilanjutkan dengan uji lanjutan Schefee. Uji prasyarat analisis data setelah perlakuan terdiri dari uji normalitas menggunakan Uji Liliefors dan uji homogenitas menggunakan Uji Fisher. Uji analisis data dilakukan menggunakan Uji anava RAK (Rancangan Acak Kelompok).

\section{HASIL DAN PEMBAHASAN}

Berdasarkan alur penelitian pada teknik pengumpulan data, maka peneliti melakukan beberapa uji sebagai berikut:

Uji prasyarat Analisis Data Sebelum perlakuan disajikam dalam Tabel 1.

TABEL 1. Hasil Uji Normalitas Sebelum Perlakuan

\begin{tabular}{|l|l|l|l|}
\hline \multicolumn{1}{|c|}{ Kelas } & \multicolumn{1}{c|}{$\boldsymbol{L}_{0}$} & $\boldsymbol{L}_{\text {tabel }}$ & \multicolumn{1}{c|}{ Interpretasi } \\
\hline X CP 1 & 0,248 & 0,147 & Tidak normal \\
\hline X CP 2 & 0,071 & 0,147 & Normal \\
\hline X CP 3 & 0,101 & 0,156 & Normal \\
\hline
\end{tabular}

Berdasarkan Tabel 1 diketahui bahwa kedua kelas yang diuji memiliki nilai L0 < Ltabel, sehingga diperoleh bahwa kedua kelas tersebut berdistribusi normal. Hasil uji homogenitas sebelum perlakuan disajikan dalam Tabel 2.

Tabel 2. Hasil Uji Homogenitas Sebelum Perlakuan

\begin{tabular}{|c|c|c|}
\hline$x^{2}$ & $x^{2}(1-\alpha)(k-1)$ & Interpretasi \\
\hline 0,443 & 0,562 & Homogen \\
\hline
\end{tabular}


Berdasarkan Tabel 2 diketahui bahwa nilai $x^{2}<x^{2}(1-\alpha)(k-1)$, sehingga dapat disimpulkan bahwa kedua kelas tersebut memiliki varians yang sama atau homogen. Hasil uji kesamaan rata-rata disajikan dalam Tabel 3.

TABEL 3. Hasil Uji Kesamaan Rata-rata

\begin{tabular}{|c|c|c|}
\hline $\mathbf{F}_{\text {hitung }}$ & $\mathbf{F}_{\text {tabel }}$ & Interpretasi \\
\hline 4,616 & 3,980 & Tidak sama \\
\hline
\end{tabular}

Berdasarkan Tabel 3 diketahui bahwa nilai Fhitung $>$ Ftabel, sehingga dapat disimpulkan bahwa kedua kelas tersebut tidak memiliki kesamaan rata-rata, maka akan dilanjutkan dengan uji lanjutan yaitu uji Schefee. Hasil uji schefee disajikan dalam Tabel 4.

TABEL 4. Hasil Uji Scheffe

\begin{tabular}{|c|c|c|c|c|}
\hline Kelas & $F_{S}$ & $F_{\text {tabel }}$ & Kesimpulan & Kesimpulan \\
\hline X CP 2 dan X CP 3 & 0,025 & 3,980 & $F_{S}<F_{\text {tabel }}$ & Terima $H_{0}$ \\
\hline
\end{tabular}

Dari pasangan kelas tersebut diketahui bahwa X CP 2 dan X CP 3 memiliki kesamaan rata-rata pada taraf signifikansi $\alpha=0,05$. Dari kelas tersebut dipilih kelas secara acak untuk dijadikan 1 kelas eksperimen dan 1 kelas konrol dengan teknik Cluster Random Sampling sehingga terpilih kelas X CP 2 sebagai kelas eksperimen dan X CP 3 sebagai kelas kontrol. Uji Prasyarat Analisis Data Setelah Perlakuan disajikan dalam Tabel 5.

TABEL 5. Hasil Uji normalias Setelah Perlakuan

\begin{tabular}{|l|l|l|c|c|}
\hline Kelas & Lhitung & Ltabel & Keterangan & Kesimpulan \\
\hline Eksperimen & 0,071 & 0,147 & Lhitung < Ltabel & Terima $H_{0}$ \\
\hline Kontrol & 0,101 & 0,156 & Lhitung < Ltabel & Terima $H_{0}$ \\
\hline
\end{tabular}

Berdasarkan tabel 5 diketahui bahwa kedua kelas memiliki nilai Lhitung < Ltabel sehingga diperoleh kesimpulan bahwa kedua kelas tersebut berdistribusi normal. Hasil uji homogenitas setelah perlakuan disajikan dalam Tabel 6.

TABEL 6. Uji Homogenitas Setelah Perlakuan

\begin{tabular}{|c|c|c|c|c|}
\hline$F_{\text {hitung }}$ & $F_{\left(1-\frac{1}{2} \alpha\right)\left(n_{1}-1, n_{2}-1\right)}$ & $F_{\left(\frac{1}{2} \alpha\right)\left(n_{1}-1, n_{2}-1\right)}{ }^{*}$ & Keterangan & Kesimpulan \\
\hline 2,006 & 0,502 & 2,019 & $\begin{array}{l}F_{\left(1-\frac{1}{2} \alpha\right)\left(n_{1}-1, n_{2}-1\right)} \\
\quad<F_{\text {hit }}< \\
F_{\left(\frac{1}{2} \alpha\right)\left(n_{1}-1, n_{2}-1\right)}\end{array}$ & Terima $\mathrm{H}_{0}$ \\
\hline
\end{tabular}

Berdasarkan tabel 6 diketahui bahwa kedua kelas memiliki nilai $\mathrm{F}_{\left(1-\frac{1}{2} \alpha\right)\left(\mathrm{n}_{1}-1, \mathrm{n}_{2}-1\right)}<\mathrm{F}_{\text {hit }}<$ $\mathrm{F}_{\left(\frac{1}{2} \alpha\right)\left(\mathrm{n}_{1}-1, \mathrm{n}_{2}-1\right)}$ sehingga diperoleh kesimpulan bahwa kedua kelas tersebut memiliki varians sama atau homogen. Uji analisis data disajikan Tabel 7.

TABEL 7. Uji Analisi Data Setelah Perlakuan

\begin{tabular}{|c|l|c|c|}
\hline $\mathbf{F}_{\text {hitung }}$ & $\mathbf{F}_{\text {tabel }}$ & Keterangan & Kesimpulan \\
\hline 5,0100 & 19 & Fhit Perlakuan $<$ Ftab & Terima $\mathrm{H}_{0}$ \\
\hline 164,9306 & 18,5128 & Fhit Kelompok $>$ Ftab & Tolak $\mathrm{H}_{0}$ \\
\hline
\end{tabular}


Berdasarkan tabel 7. Hasil pengujian terhadap perlakuan menunjukkan Fhitung < Ftabel 5\%, hal ini berarti perlakuan model pembelajaran SAVI dan konvensional yang dilakukan tidak memberi pengaruh dalam mengendalikan kemampuan pemecahan masalah matematika siswa. Hasil Pengujian terhadap kelompok menunjukkan Fhitung> Ftabel 5\% hal ini berarti pengelompokkan tingkat kemampuan awal matematika (tinggi, sedang, rendah) yang berbeda terdapat perbedaan yang nyata terhadap kemampuan pemecahan masalah matematika siswa. Uji lanjut Duncan disajikan Tabel 8.

TABEL 8. Uji lanjut Duncan

\begin{tabular}{|l|c|c|c|c|c|}
\hline \multirow{2}{*}{ Perlakuan } & \multicolumn{3}{|c|}{ Kelompok } & \multirow{2}{*}{ Total } & \multirow{2}{*}{ Rata-rata } \\
\cline { 2 - 4 } & Tinggi & Sedang & Rendah & & \\
\hline SAVI (P0) & 1036,29 & 993,14 & 807,91 & 2837,34 & $945,78^{\text {a }}$ \\
\hline Konvensional (P1) & 398,64 & 242,48 & 231,75 & 873,26 & $291,08^{\text {a }}$ \\
\hline
\end{tabular}

Berdasarkan tabel 8, hasil uji Duncan menunjukkan perlakuan dengan kelompok rendah tetapi mempunyai perbedaan signifikan yang sama dengan perlakuan kelompok yang tinggi dalam meningkatkan kemampuan pemecahan masalah matematika, maka perlakuan kelompok yang rendah lebih baik daripada perlakuan kelompok sedang maupun tinggi. Dalam penelitian ini perlakuan model SAVI dengan tingkat atau kelompok rendah lebih baik karena mempunyai perbedaan yang signifikan dalam meningkatkan kemampuan pemecahan masalah matematika dari pada perlakuan model konvensional.

Penyebab kemampuan pemecahan masalah matematika siswa pada kelas yang menerapkan model pembelajaran SAVI lebih tinggi daripada kemampuan pemecahan masalah matematika siswa pada kelas yang menerapkan model pembelajaran konvensional dapat terjadi karena adanya perbedaan kegiatan kelas pada kelas eksperimen dan kelas kontrol. Kegiatan pembelajaran pada kelas yang menerapkan SAVI dengan pengelompokkan siswa berdasarkan tingkat kemampuan awal matematika siswa bertujuan untuk mengembangkan kemampuan pemecahan masalah matematika siswa. Kegiatan pembelajaran di kelas penelitian yang menerapkan model pembelajaran SAVI dengan pengelompokkan siswa berdasarkan tingkat kemampuan awal matematika siswa terdiri dari kegiatan pendahuluan, kegiatan inti dan kegiatan penutup. Pada kegiatan pendahuluan guru memulai pembelajaran dengan mengucapkan salam, berdoa, memberitahukan kepada siswa mengenai topik materi pelajaran yang akan dipelajari, tujuan pembelajaran, model pembelajaran yang akan digunakan yaitu model pembelajaran SAVI. Setelah itu guru membagi kelompok berdasarkan hasil dari tes kemampuan awal matematika siswa yang terdiri dari 4-5 orang. Hal ini bertujuan menuntut siswa dalam bekerja sama dan kontribusi setiap anggota kelompok dalam memahami materi dan memecahkan masalah matematika.

Pada kegiatan inti, siswa mengikuti empat tahapan model pembelajaran SAVI. Pada tahap pertama dalam kegiatan inti siswa diarahkan untuk membaca/mempelajari materi aturan sinus dan cosinus yang terdapat pada buku pegangan siswa maupun dari sumber lain. Mintalah siswa berpasang-pasangan membincangkan secara terperinci apa yang mereka baru saja mereka pelajari dan bagaimana mereka akan menerapkannya (Auditory) sesuai dengan hasil penelitian sebelumnya yang dilakukan oleh Khaidir (2012). Meminta siswa mempraktikkan suatu ketrampilan atau memperagakan suatu fungsi sambil mengucapkan secara singkat terperinci apa yang sedang mereka baca. Sesuai dengan hasil penelitian sebelumnya oleh Ulvah dan Afriansyah (2016) siswa selalu siap ketika ditanya dan diminta untuk menjelaskan dari setiap masalah yang diberikan.

Pada tahap kedua guru mendorong siswa untuk mengajukan pertanyaan yang terkait dengan materi aturan sinus dan cosinus yang telah dipelajari dari buku pegangan siswa maupun dari sumber lain. Somatic terlihat pada kegiatan siswa bergerak dan memeragakan suatu proses, sistem, atau seperangkat konsep sesuai dengan penelitian yang dilakukan oleh Haruminati, Suarni, dan Sudarma (2016). Meminta siswamenjalankan pelatihan belajar aktif seperti simulasi (Somatic), permainan belajar, dan lain-lain. Unsur somatic diantaranya merangsang hubungan pikiran dan tubuh dalam pembelajaran matematika, maka perlu diciptakan suasana belajar yang dapat membuat siswa bangkit dan berdiri kegiatan ini bisa diterapkan setelah siswa mendapatkan pemahaman dari suatu materi aturan sinus dan cosinus lalu menceritakannya dan merefleksikannya dengan meminta perwakilan kelompok untuk 
menuliskan dan mengerjakan dipapan tulis sesuai dengan pembahasan pada penelitian yang dilakukan oleh Putra (2013).

Pada tahap ketiga siswa diberi kesempatan untuk memberikan tanggapan. Jika diperlukan guru memberikan konfirmasi atas pertanyaan atau tanggapan siswa. Guru bisa memberikan gambaran yang tepat dalam bentuk gambar (Visual) sesuai dengan materi aturan sinus dan cosinus. Memberikan penerapan secara kontekstual atau nyata dalam kehidupan sehari-hari. Sesuai dengan hasil penelitian sebelumnya oleh Ulvah dan Afriansyah (2016) siswa mulai terbiasa dengan masalah-masalah yang disajikan dalam lembar kerja (Visual) yang diberikan, mereka selalu memperhatikan setiap langkah yang telah disediakan dalam lembar kerja (Visual).

Pada tahap ke empat guru meminta siswa dalam setiap kelompok diarahkan untuk memahami masalah, dengan membahas masalah yang ada pada buku pegangan siswa, siswa dalam setiap kelompok diminta untuk mengemukakan hasil diskusi/kesimpulan tentang aturan sinus dan cosinus. Unsur Intellectual diantaranya adalah merumuskan pertanyaan, mencari dan menyaring informasi, menganalisis pengamatan, mengerjakan perencanaan strategis, melahirkan gagasan kreatif, memecahkan masalah sesuai dengan pembahasan penelitian yang dilakukan oleh Kusumawati (2014). Secara berkelompok, siswa diarahkan untuk menyelesaikan soal/masalah yang disajikan dalam lembar aktivitas siswa (LAS). Jika diperlukan guru memberikan konfirmasi jawaban yang benar dari soal/masalah yang diberikan. Persaingan antar kelompok semakin membuat mereka lebih bersemangat dalam berdiskusi dan mengerjakan lembar kerja yang diberikan, sesuai dengan hasil penelitian yang dilakukan oleh Ulvah dan Afriansyah (2016).

Pada kegiatan penutup, Siswa dengan bimbingan guru, membuat resume/rangkuman tentang aturan sinus dan cosinus. Guru memberikan tugas kepada siswa untuk memilih soal dari buku siswa atau buku sumber lain yang berkaitan dengan materi aturan sinus dan cosinus serta menyelesaikannya. Guru meminta siswa diingatkan untuk mempelajari materi yang akan dibahas pada pertemuan berikutnya. Secara individual, siswa diminta untuk menyelesaikan soal tentang aturan sinus dan cosinus sebagai evaluasi kemampuan pengetahuan siswa.

Pembelajaran kelas kontrol yang menerapkan model pembelajaran konvensional sangat berbeda dengan pembelajaran pada kelas eksperimen yang menerapkan model pembelajaran SAVI dengan pengelompokkan siswa berdasarkan tingkat kemampuan awal matematika siswa. Pada pembelajaran konvensional, guru tidak menggunakan media pembelajaran sama sekali dan siswa tidak diberikan LAS sehingga proses pembelajaran membutuhkan waktu yang lebih lama karena siswa harus mencatat materi pelajaran, contoh soal, dan latihan soal pada buku catatan. Pada pembelajaran konvensional, siswa tidak terlibat aktif dalam kegiatan pembelajaran karena siswa lebih banyak mendengarkan ceramah dari guru. Hal ini sesuai dengan teori yang dikemukakan oleh Lapp, Bender, Ellenwod, dan John (dalam Aunurrahman, 2013) bahwa model konvensional atau klasikal adalah model pembelajaran dimana gurumenitikberatkan perannya dalam pemberian informasi melalui mata pelajaran dan materi yang disajikan atau dengan kata lain bahwa pembelajaran berpusat pada guru. Selain itu siswa tidak dapat memecahkan permasalahan secara mandiri karena siswa lebih sering diberikan soal rutin dan terbiasa hanya mengikuti cara pengerjaan yang telah diberi oleh guru, kemudian komunikasi antara siswa tidak terfasilitasi karena tidak ada kegiatan pembelajaran secara berkelompok dan semua tugas atau latihan soal dikerjakan secara individu.

Pada intinya, untuk kelas eksperimen dengan tingkat kemampuan awal matematika siswa yang berbeda siswa benar-benar terlibat dalam pembelajarannya, mereka terlihat nyaman dengan model pembelajaran SAVI yang diterapkan. Berbeda dengan kelas kontrol yang menggunakan model pembelajaran konvensional dengan tingkat kemampuan awal matematika siswa yang berbeda, yang terlibat dalam pembelajaran hanya sebagian, hanya siswa-siswa yang mempunyai kemampuan lebih dalam bidang matematika. Sebagian siswa yang terlihat kemampuannya kurang mereka semakin terlihat bosan untuk belajar matematika. Hal tersebut mungkin disebabkan karena proses yang digunakan dalam pembelajaran terkesan membosankan. Terlihat dari hasil nilai rata-rata post test kemampuan pemecahan masalah matematika siswa kelas eksperimen lebih baik daripada kelas kontrol.

Kekurangan yang dialami oleh peneliti saat melaksanakan penelitian di sekolah tersebut adalah jumlah kelas yang diajar oleh guru yang sama terbatas yaitu hanya tersedia tiga kelas (X CP 1, X CP 2 dan X CP 3), jumlah siswa dalam kelas eksperimen (36 siswa) berbeda dengan jumlah siswa dalam 
kelas kontrol (32 siswa), sistem belajar yang menggunakan pindah kelas (Moving class) membuat siswa terkadang terlambat masuk kelas. Berdasarkan uraian diatas, dapat dikatakan bahwa kegiatan pembelajaran pada model pembelajaran SAVI yang ditinjau dari tingkat kemampuan awal matematika siswa lebih baik dibandingkan dengan model pembelajaran konvensional dalam mengembangkan kemampuan pemecahan masalah matematika siswa. Oleh karena itu, terdapat perbedaan signifikan dari penerapan model pemebelajaran SAVI yang ditinjau dari tingkat kemampuan awal rendah terhadap kemampuan pemecahan masalah matematika siswa kelas X CP (Cetak Produksi) 2 dengan X CP (Cetak Produksi) 3 SMK Negeri 7 Jakarta.

\section{PENUTUP}

\section{Kesimpulan}

Berdasarkan tujuan penelitian ini adalah untuk menguji pengaruh pembelajaran matematika menggunakan model kooperatif tipe SAVI (Somatic, Auditory, Visual, Intellectual) terhadap kemampuan pemecahan masalah matematika ditinjau dari tingkat kemampuan awal matematika siswa, jika dibandingkan dengan pembelajaran matematika menggunakan pembelajaran konvensional. Hasil penelitian yang telah dilakukan, diperoleh kesimpulan bahwa terdapat perbedaan kemampuan pemecahan masalah matematis antara siswa yang belajar dengan menggunakan model pembelajaran kooperatif SAVI (Somatic, Auditory, Visual, Intellectual) ditinjau dari tingkat kemampuan awal matematika siswa dengan siswa yang belajar dengan menggunakan model konvensional. Hal ini ditinjau berdasarkan hasil perhitungan anava rancangan acak kelompok yang diperoleh terhadap perlakuan model pembelajaran menunjukkan Fhitung= 5,010 dan Ftabel= 19 sehingga Fhitung < Ftabel sehingga terima $\mathrm{H} 0$, hal ini berarti perlakuan model pembelajaran SAVI dan konvensional yang dilakukan tidak memberi pengaruh dalam mengendalikan kemampuan pemecahan masalah matematika siswa. Hasil pengujian terhadap kelompok menunjukkan Fhitung= 164,930 dan Ftabel= 18,513 sehingga Fhitung $>$ Ftabel hal ini berarti pengelompokkan tingkat kemampuan awal matematika (tinggi, sedang, rendah) dapat memberi pengaruh yang nyata terhadap kemampuan pemecahan masalah matematika siswa. Uji lanjut Duncan menghasilkan perlakuan dengan kelompok rendah tetapi mempunyai pengaruh yang sama dengan perlakuan kelompok yang tinggi dalam meningkatkan kemampuan pemecahan masalah matematika, maka perlakuan kelompok yang rendah lebih baik daripada perlakuan kelompok sedang maupun tinggi. Dalam penelitian ini perlakuan model SAVI dengan kelompok rendah lebih baik dari pada perlakuan model konvensional. Dengan demikian, model pembelajaran SAVI dengan kemampuan awal matematika rendah memberikan perbedaan signifikan terhadap kemampuan pemecahan masalah matematika siswa kelas X CP (Cetak Produksi) 2 dan kelas X CP (Cetak Produksi) 3 SMK Negeri 7 Jakarta. Beberapa faktor yang mempengaruhi dari hasil penelitian penulis adalah jumlah kelas yang diajar oleh guru yang sama terbatas yaitu hanya tersedia tiga kelas ( X CP 1, X CP 2 dan X CP 3), jumlah siswa dalam kelas eksperimen (36 siswa) berbeda dengan jumlah siswa dalam kelas kontrol (32 siswa), sistem belajar yang menggunakan pindah kelas (Moving class) membuat siswa terkadang terlambat masuk kelas. Kepada penelitian selanjutnya yang hendak melakukan penelitian dengan model yang sama bisa dilihat dari pengkategorian berdasarkan tingkat kemampuan awal matematika siswa (tinggi, sedang dan rendah) dan diharapkan agar setiap tingkat kemampuan awal matematika memberikan perbedaan yang signifikan terhadap kemampuan pemecahan masalah matematika siswa.

\section{REFERENSI}

Aunurrahman. (2013). Belajar dan Pembelajaran. Bandung: Alfabeta.

Haruminati, N. W. Y., Suarni, N. K., \& Sudarma, I. K. (2016). Pengaruh Model Pembelajaran Savi Terhadap Minat Belajar Matematika Siswa Kelas IV SD Mutiara Singaraja. Mimbar Pgsd, 4(1), 1-11. Retrieved from https://ejournal.undiksha.ac.id/index.php/JJPGSD/article/view/6982

Harususilo, Y. E. (2019). Skor PISA Terbaru Indonesia, Ini 5 PR Besar Pendidikan pada Era Nadiem Makarim. 
Khaidir, C. (2012). Pembelajaran Matematika dengan Model SAVI Berorientasi Pakem. (137).

Kusumawati, S. W. (2014). Penerapan Model Pembelajaran SAVI Untuk Meningkatkan Keterampilan Pemecahan Masalah Di Sekolah Dasar Sri Wahyuni Kusumawati Pgsd Fip Universitas Negeri Surabaya. Jpgsd, p. 1.

Lutfianto, M., Zulkardi, \& Hartono, Y. (2013). Unfinished student answer in Pisa mathematics contextual problem. Journal on Mathematics Education, 4(2), 188-193. https://doi.org/10.22342/jme.4.2.552.188-193

Meier, D. (2002). The Accelerated Learning Handbook (diterjemahkan oleh: Rahmani Astuti). Bandung: Kaifa.

National Council of Teachers of Mathematics (NCTM). (2000). Principles and Standards for School Mathematics. tersedia di www.nctm.org.

Putra, H. D. (2013). Pembelajaran Geometri dengan Pendekatan SAVI Berbantuan Wingeom untuk Meningkatkan KemampuanGeneralisasi Matematis Siswa SMP. Journal of Black Studies, 17(5), 684-694. https://doi.org/10.1017/CBO9781107415324.004

Taneo, P. N. L. (2017). Pembelajaran Model SAVI Berpendekatan Kontekstual Terhadap Kemampuan Pemecahan Masalah Matematika Siswa. JPMI (Jurnal Pendidikan Matematika Indonesia), 1(1), 14. https://doi.org/10.26737/jpmi.v1i1.77

Ulfa, K., Buchori, A., \& Murtianto, Y. H. (2017). Efektivitas Model Guided Discovery Learning Untuk Video Pembelajaran Dalam Mengetahui Perbedaan Kemampuan Pemecahan Masalah Matematika Siswa. 2(2), 267-275.

Ulvah, S., \& Afriansyah, E. A. (2016). Kemampuan Pemecahan Masalah Matematis Siswa ditinjau melalui Model Pembelajaran SAVI dan Konvensional. Jurnal Riset Pendidikan, 2(2), 142-153. Retrieved from http://hikmahuniversity.ac.id/lppm/jurnal/2016/text07.pdf

Zannah, N. (2017). Karakteristik Intuisi Siswa Dalam Memecahkan Masalah Matematika Ditinjau Dari Gaya Kognitif Dan Perbedaan Gender. (2), 111-119 